\title{
Estudo morfológico dos órgãos genitais masculinos do guaxinim (Procyon cancrivorus) ${ }^{1}$
}

\author{
Mariane Ferracin Martucci², Celina Almeida Mançanares², Carlos Eduardo. Ambrósio ${ }^{4}$, \\ André Luis Rezende Franciolli ${ }^{3 *}$, Maria Angélica Miglino ${ }^{3}$, Ricardo Alexandre Rosa ${ }^{2}$ \\ e Ana Flávia de Carvalho ${ }^{2}$
}

\begin{abstract}
Martucci M.F., Mançanares C.A.F., Ambrósio C.E., Franciolli A.L.R., Miglino M.A., Rosa R.A. \& Carvalho A.F. 2011. [Morphological study of raccon male genital organs (Procyon cancrivorus).] Estudo morfológico dos órgãos genitais masculinos do guaxinim (Procyon cancrivorus). Pesquisa Veterinária Brasileira 31(11):1024-1030. Departamento de Morfologia, Faculdade de Medicina Veterinária, Centro Universitário da Fundação de Ensino Octávio Bastos, Av. Octávio Bastos s/n, Jardim Nova São João, São João da Boa Vista, SP 13870-000, Brazil.E-mail: andrefranciolli@usp.br

Three animals were used in this study, proceeding from the University of Sao Paulo for the Laboratory of Morphology of the University Center of the Foundation of Education Octávio Bastos and one other directed by the IBAMA in accordance with process number 02027.000.286/2004-92, population excess of zoo, whose masculine reproductive devices "former situ" had been fixed by immersion and dissected. Each agency and attached gland of the reproductive device had been removed fragments of, which had been processed and enclosed by the techniques of inclusion in paraplast. Each block was cut and the cuts had been corados by HE, picrosírius, and histochemical reaction of PAS with deep of blue hematoxilina and Masson Tricrome for the comment of the structures to the optic microscope. Macroscopically, the inguinal region was composed by the urethra, isquiocavernosum muscle, bulbospongiosus and bulbcavernosum muscles, penis retractor muscle, a pair of testicles and penile bone or baculum and anus. The head of the penis presented a proximal dilatation constituted on the widest part of baculum. The position of the testes inside the scrotum was horizontal. The prostate gland was in globoid form surrounding the urethra. Microscopically, the testes were coated by dense connective tissue, the tunica albuginea. The ductus epididymis was coated by pseudostratified epithelia with stereocilia. The urethra of the penis was surrounded by the corpus spongiosum and the remaining portion presented a corpus cavernosum (erectile tissue). The found macro and microscopically results and until the moment are similar to the findings in the Cannis familiaris (domestic dog).
\end{abstract}

INDEX TERMS: Carnivores, Morphology, Procyonidae, Wild animals.

RESUMO.- Foram utilizados três animais, sendo um proveniente da Universidade de São Paulo e dois encaminhados pelo IBAMA (Proc. 02027.000.286/2004-92), exceden-

\footnotetext{
${ }^{1}$ Recebido em 16 de julho de 2011.

Aceito para publicação em 2 de setembro de 2011.

${ }^{2}$ Centro Universitário da Fundação de Ensino Octávio Bastos, Av. Octávio Bastos s/n, Jd. Nova São João, São João da Boa Vista, SP 18870-000, Brasil. *Autor para correspondência: andrefranciolli@usp.br

${ }^{3}$ Departamento de Cirurgia, Faculdade de Medicina Veterinária e Zootecnia, Universidade de São Paulo (USP), Av. Prof. Orlando Marques de Paiva 87, Cidade Universitária, São Paulo, SP 05508-270, Brasil.

${ }^{4}$ Departamento de Ciências Básicas, Faculdade de Zootecnia e Engenharia de Alimentos, Campus da USP, Av. Duque de Caxias Norte 225, Pirassununga, SP 13635-900, Brasil.
}

te populacional de zoológico. Os aparelhos reprodutores masculinos "ex situ" foram fixados por imersão e dissecados. Foram retirados fragmentos de cada órgão e glândula anexa do aparelho reprodutor, os quais foram processados e incluídos pelas técnicas de inclusão em paraplast. Cada bloco foi cortado e os cortes foram corados por HE, picrosírius, reação de PAS com fundo de hematoxilina e tricromo de masson para a observação das estruturas ao microscópio óptico. Macroscopicamente, a região inguinal era composta pela uretra, músculo isquiocavernoso, músculos bulboesponjoso e bulbo cavernoso, músculo retrator do pênis, um par de testículos e o osso peniano ou báculo e ânus. A glande do pênis apresentou uma dilatação proximal (bul- 
bo da glande) constituída pela parte dilatada do báculo. A posição dos testículos, dentro do escroto, era horizontal. A próstata apresentou-se com formato globoso, circundando a uretra. Microscopicamente, os testículos eram envoltos por uma cápsula de tecido conjuntivo denso, a túnica albugínea testicular. 0 ducto epididimário era provido de um epitélio pseudoestratificado com estereocílios. A uretra peniana apresentou-se circundada pelo corpo esponjoso e no restante do pênis apresentou o corpo cavernoso (tecido erétil). Os resultados macro e microscópicos encontrados até o momento são semelhantes aos achados no Canis familiaris (cão doméstico).

TERMOS DE INDEXAÇÃO: Animais silvestres, carnívoros, morfologia, Procionídeos.

\section{INTRODUÇÃO}

Procyon lotor, guaxinim, "mão pelada" ou raccon, como é conhecido nos Estados Unidos, pertence ao Reino Animal, Filo Chordata, Classe Mammalia, Família Procyonidae, Ordem Carnívora (Zeller 1999). No Brasil a espécie existente é Procyon cancrivorus. Podem medir $60 \mathrm{~cm}$ de comprimento e mais $40 \mathrm{~cm}$ de cauda e pesar até $20 \mathrm{~kg}$. Em cativeiro estes animais recebem como alimentação uma ração diária semelhante ao dos gatos domésticos e furões. Eles possuem hábitos noturnos, podendo às vezes, ser ativo durante o dia (Labate et al. 2001, Rodrigues et al. 2007, Bellatine et al. 2010), tornando-se veiculadores de zoonoses tais como o vírus da CDV canina (cinomose) (Machida 1993) e Coxiella burnetii (Ejercito et al. 1993).

Os órgãos genitais masculinos são os dois testículos, as glândulas reprodutivas essenciais (onde se realiza a produção de espermatozóides e testosterona) com suas coberturas e anexos, o epidídimo (que acumula e transporta o espermatozóide), o ducto deferente, o ducto dos testículos, as glândulas seminais (vesícula seminal no equino), a próstata (órgão músculo glandular), as duas glândulas bulbouretrais (ou de Cowper), a uretra masculina, um canal que transmite as secreções reprodutivas e urinárias e o pênis, o órgão copulatório masculino (Ellenport 1986).

Dyce et al. (1997) relataram que os órgãos reprodutivos (genitais) do macho incluem gônadas pares, os testículos, que produzem tanto gametas masculinos (espermatozóides) como hormônios; sistemas de ductos gonadais pares, cada um deles consistindo em epidídimo e ducto deferente, que transportam os produtos exócrinos do testículo para a uretra; um conjunto de glândulas acessórias: glândula ampular, glândula vesicular, próstata, glândula bulbouretral, que contribuem para o volume do sêmen, porém, nem todas estão presentes nas espécies animais; a uretra masculina, que se estende de um óstio interno no colo da bexiga até um óstio externo na extremidade livre do pênis e serve tanto para passagem de urina como de sêmen; o pênis, órgão copulador masculino, que deposita o sêmen dentro do trato reprodutivo da fêmea e adaptações da pele, o escroto e o prepúcio, desenvolvidos com relação aos testículos e ao pênis.

As gônadas masculinas (testículos) situam-se fora do abdome, no escroto, uma estrutura semelhante a uma bol- sa, derivada da pele e da fáscia da parede abdominal. 0 testículo localiza-se dentro do processo vaginal, uma extensão separada do peritônio, o qual atravessa a parede abdominal pelo canal inguinal. Os vasos e os nervos alcançam os testículos no funículo espermático, que se posiciona dentro do processo vaginal; o ducto deferente acompanha os vasos, mas se separa deles no orifício do processo vaginal para se unir à uretra. Além de permitir a passagem do processo vaginal e de seu conteúdo, o canal inguinal também dá passagem a vasos e nervos para o suprimento da genitália externa (Hafez \& Hafez 2004).

Os espermatozóides deixam o testículo pelos ductos eferentes e vão em direção ao ducto espiralado do epidídimo, que continua como ducto deferente. As glândulas acessórias eliminam seus conteúdos no ducto deferente ou na porção pélvica da uretra (Hafez \& Hafez 2004).

As glândulas ou vesículas seminais, a próstata e as glândulas bulbouretrais, lançam suas secreções dentro da uretra, onde se misturam com o fluido secretado pelos testículos, assim, são muitas vezes denominadas de glândulas sexuais acessórias. As glândulas vesiculares são órgãos pares que estão ausentes no carnívoro e que, portanto, não se acredita serem essenciais para a reprodução. As glândulas prostáticas são encontradas em quase todos os mamíferos, ocorrendo dois tipos: o disseminado (ovino e caprino) e o lobulado (eqüino e canino), já o touro e o porco possuem uma próstata que reúne as características de ambos os tipos. O par de glândulas bulbouretrais está ausente no cão e é muito pequeno no gato (Ellenport 1986).

Os testículos dos mamíferos devem ser mantidos em uma temperatura mais baixa que a do corpo, para um funcionamento eficiente. Características anatômicas dos testículos e do escroto permitem a regulação da temperatura testicular. Em condições de frio, os músculos lisos no interior do funículo espermático e túnica albugínea se contraem, elevando o testículo, enrugando e engrossando a parede do escroto. Em condições de calor, os músculos relaxam, abaixando o testículo para o interior do escroto penduloso e de parede fina. As vantagens oferecidas por esse mecanismo são realçadas pela relação especial das artérias e veias (Hafez \& Hafez 2004).

Histologicamente, os testículos são órgãos exócrinos e endócrinos combinados onde à porção exócrina é uma glândula tubular composta enovelada cujo produto de secreção holócrina são os espermatozóides. A porção endócrina é representada pelas células intersticiais de Leidig e pelas células de sustentação de Sertoli. 0 envoltório testicular caracteriza-se por uma cápsula de tecido conjuntivo denso revestido pela túnica serosa, cujo tecido conjuntivo se mescla ao da túnica albugínea. 0 parênquima do órgão é formado pelas células de revestimento dos túbulos seminíferos e seus ductos, assim como pelas células intersticiais de Leidig. Os túbulos seminíferos são responsáveis pela produção de espermatozóide, apresentando-se enovelados (Banks 1992, George \& Castro 1998, Gartner 1999, Junqueira \& Carneiro 2004, Kerr 2000).

0 ducto do epidídimo apresenta epitélio da mucosa pseudoestratificado prismático com estereocílios, a lâmina própria é formada por tecido conjuntivo frouxo altamente 
vascularizado, a muscular da mucosa é circular e se espessa à medida que se aproxima da cauda do epidídimo. 0 ducto deferente sai do epidídimo e termina na uretra prostática, onde despeja seu conteúdo. É caracterizada por um lúmen estreito e espessa camada muscular lisa. 0 músculo liso sofre contrações peristálticas que auxiliam na expulsão do sêmen durante a ejaculação (Junqueira \& Carneiro 2004).

No que se referem às glândulas acessórias, de forma geral, todas elas são glândulas tubulares ramificadas ou tubuloalveolares ramificadas dispostas em unidades tubulares. 0 epitélio glandular é formado pelo revestimento prismático simples que é contínuo com o epitélio pseudoestratificado ou de transição dos ductos excretores (Menezes et al. 2010). Embora as glândulas de uma mesma espécie possam ser facilmente distinguidas, deve-se tomar cuidado com as comparações interespecíficas, pois há muita variação entre as espécies domésticas. Anatomicamente, o pênis está dividido em raiz, corpo e glande. 0 corpo é formado pela cápsula, pelo tecido erétil, músculo liso, músculo esquelético e uretra, constituição semelhante a da raiz. A glande é revestida pelo prepúcio, que é uma dobra de pele, portanto, é uma membrana mucosa. A maior parte da glande consiste em tecido conjuntivo frouxo altamente vascularizado. Esta estrutura pode conter tecido erétil, osso, cartilagem e tecido conjuntivo denso, dependendo da espécie (Banks 1992, George \& Castro 1998, Gartner 1999, Junqueira \& Carneiro 2004).

O sêmen é a suspensão celular líquida contendo espermatozóides (gametas masculinos) e secreção dos órgãos acessórios do trato genital masculino. A porção fluida dessa suspensão, que é formada na ejaculação, é conhecida como plasma seminal (Hafez \& Hafez 2004).

A fertilidade de um macho reprodutor está relacionada a fenômenos como produção de espermatozóides, viabilidade e capacidade fertilizante dos espermatozóides ejaculados, desejo sexual e habilidade de praticar a cobertura. 0 reprodutor infértil é rapidamente identificado, porém aquele com fertilidade reduzida apresenta sérios problemas, ocasionando perdas econômicas para criadores (Hafez \& Hafez 2004).

Este trabalho teve como objetivo descrever a morfologia macroscópica e microscópica dos órgãos genitais masculinos em Procyon cancrivorus, sua sintopia e comparação entre outras espécies, além da coleta e análise do sêmen.

\section{MATERIAL E MÉTODOS}

Para a descrição da morfologia dos órgãos genitais masculinos do Procyon cancrivorus, foram utilizados nesta pesquisa três aparelhos reprodutores masculinos, sendo um doado pela Universidade de São Paulo para o Laboratório de Morfologia do Centro Universitário da Fundação de Ensino Octávio Bastos, e dois que fazem parte de um projeto vinculado ao criatório científico, CECRIMPAS, IBAMA (Proc. 02027.000.286/2004-92), da UNIfeob. A nomenclatura utilizada foi referida conforme The International Commitee on Veterinary Gross Anatomical Nomenclature.

Análise macroscópica. Os animais foram fixados pelos processos de perfusão, injetando solução aquosa de formaldeído a $10 \%$ através da veia jugular externa, e de imersão no mesmo fixador, onde a peça permaneceu submersa por um período mínimo de 48 horas. A seguir, somente o aparelho genital masculino, "ex situ" foi dissecado, descrito e fotografado com câmera fotográfica digital.

Análise microscópica. Para a identificação das características microscópicas, foram colhidos fragmentos de cada órgão do sistema reprodutor e das glândulas acessórias. Estes fragmentos foram processados e incluídos pela técnica de inclusão em similar de parafina (Histosec ${ }^{\circledR}$, Merck, Lote K91225309) de acordo com Tolosa et al. (2003). Os blocos e suas diferentes porções foram cortados em um micrótomo Leica RM 2165, com espessura média de $5 \mu \mathrm{m}$. Os cortes foram corados seguindo as técnicas de HE (Tolosa et al. 2003), pricossírius sem polarização (Junqueira et al. 1979), reação histoquímica de PAS. (Ácido periódico de Shiff), com fundo de hematoxilina (Lillie \& Fulmer 1976) e Tricromo de Masson. 0 material foi analisado, mapeado, e fotografado através de um fotomicroscópio Eclipse Nikon E-400.

Processo de descalcificação. Fragmentos do pênis com o osso peniano foram descalcificados, pelo método de remoção de cálcio tecidual em solução de ácido fórmico formulado da seguinte maneira: $80 \mathrm{ml}$ água destilada, $120 \mathrm{ml}$ ácido fórmico, $80 \mathrm{ml}$ ácido clorídrico. 0 descalcificador foi renovado diariamente durante cinco dias, verificando-se constantemente o processo de descalcificação através da introdução de um alfinete na peça. Quando este penetrou facilmente, sem atrito entre o metal e o cálcio a peça estava descalcificada, o qual foi lavado em água corrente por 12 horas, seguindo-se os métodos convencionais para histologia (Tolosa et al. 2003).

\section{RESULTADOS E DISCUSSÃO}

A região inguinal era composta pelas seguintes estruturas: uretra, músculo isquiocavernoso, músculos bulboesponjoso e bulbo cavernoso, músculo retrator do pênis, um par de testículos e o osso peniano ou báculo, sendo esta, evidenciada em vista lateral ex situ e ânus (Fig.1A,D). A posição dos testículos dentro do escroto em relação ao eixo maior e corpóreo era horizontal, assim como descrito por Franciolli et al. (2007) no quati (Nasua nasua) outro carnívoro pertencente a Família Procyonidae. Em relação ao corpo, localizava-se entre a transição da região perineal e região inguinal, segundo descrito por Ellenport (1986). Observou-se que os testículos são revestidos por túnicas, denominadas albugínea e visceral, assim como Banks (1992) descreveu para os carnívoros domésticos (Fig.1B,C).

O pênis possuía o osso báculo, e ventralmente o músculo bulboesponjoso com coloração enegrecida devido à vascularização e fina membrana conjuntiva (Fig.2A). A vascularização do pênis era feita pela artéria e veia dorsal do pênis. A veia na base do pênis era única enquanto que na extremidade distal ou cranial era dupla. A extremidade distal ou cranial do pênis é terminada por uma fina glande triangular que reveste a extremidade do báculo. 0 báculo especificamente em sua porção distal é bilobado em forma de alteres verticais em relação ao eixo do corpo do animal (Fig.2B,C). As glândulas anexas do aparelho reprodutor masculino eram a próstata e a ampola do ducto deferente (Fig.2D), porém, Ellenport (1986) declarou que as glândulas vesiculares estão ausentes nos carnívoros e o cão particularmente não possui o par de glândulas bulbouretrais, semelhante ao Procyon cancrivorus e ao Nasua nasua, como descrito por Franciolli et al. (2007).

Histologicamente os testículos eram compostos por túbulos enovelados, chamados túbulos seminíferos, os quais se 


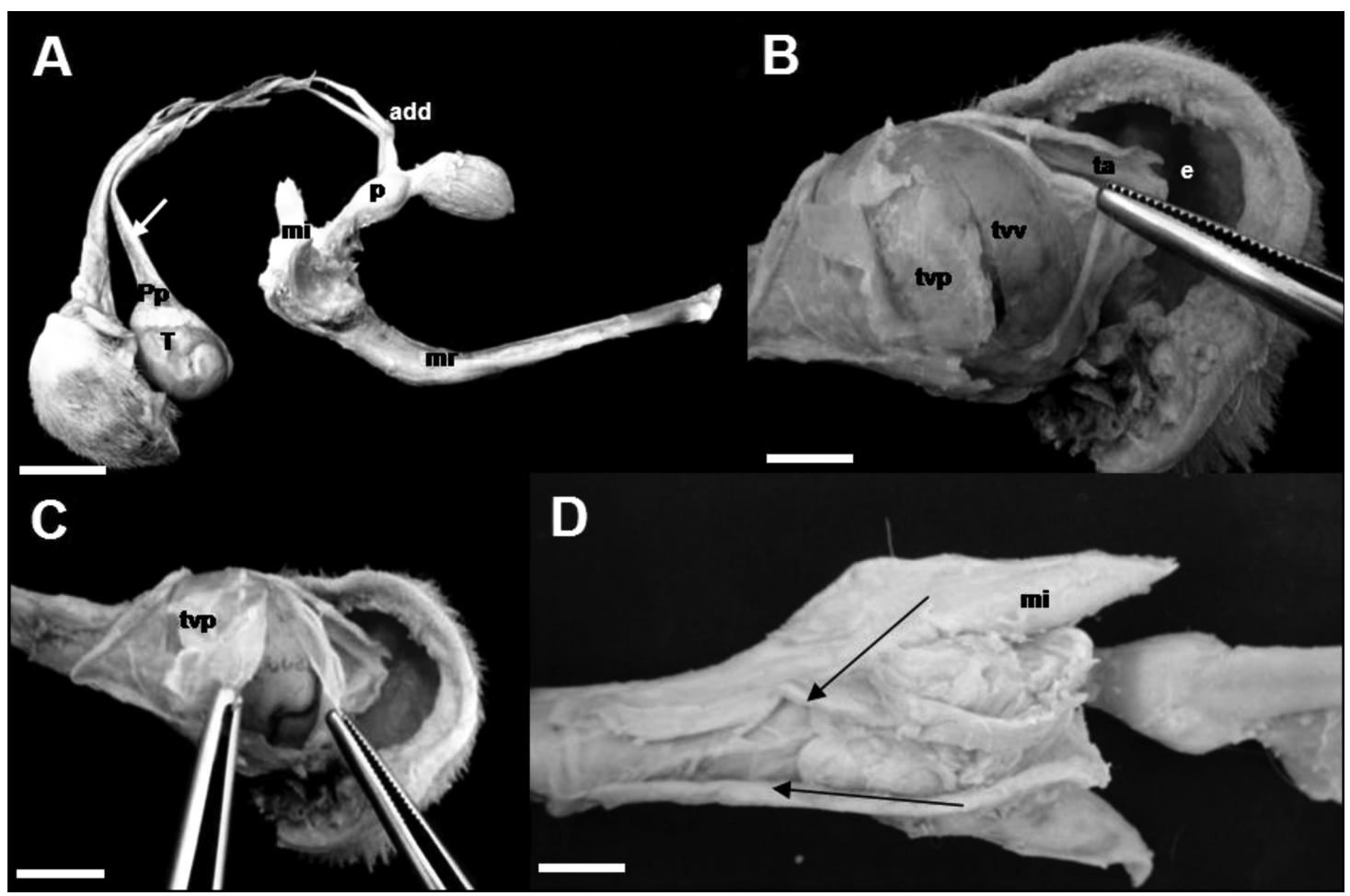

Fig.1. Órgão genital masculino de Procyon cancrivorus. (A) Testículo (T), músculo retrator do pênis (mr), plexo pampiniforme (Pp) músculo cremaster (seta), músculo isquiocavernoso (mi), próstata (p), ampola do ducto deferente (add). (B) Escroto aberto expondo as túnicas testiculares: túnica albugínea (ta), túnica vaginal parietal (tvp); túnica vaginal visceral (tvv), escroto (e). (C) Detalhe das túnicas testiculares: vaginal visceral (pinça) e vaginal parietal (tvp). (D) Vista ventral do músculo retrator do pênis formando um vértice (setas), músculo isquiocavernoso (mi). Barra: $1 \mathrm{~cm}$.

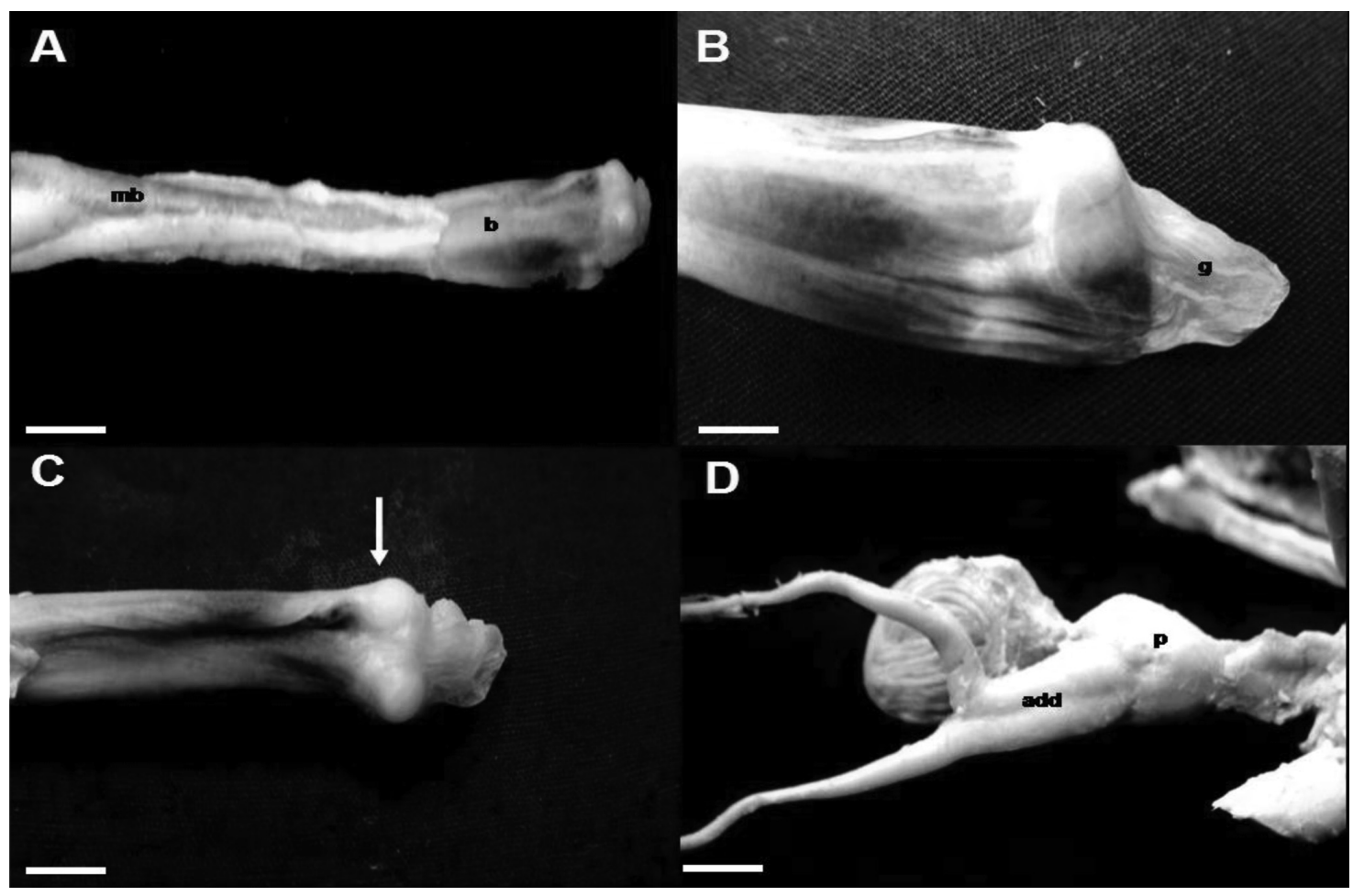

Fig.2. Região peniana. (A) Osso do báculo (b) e músculo bulboesponjoso (mb). (B) Extremidade distal ou cranial do pênis terminada por uma fina glande triangular (g) que reveste a extremidade do báculo. (C) Báculo bilobado em forma de alteres (seta). (D) Vista ventral evidenciando a ampola do ducto deferente (add) e a próstata (p). Barra: $1 \mathrm{~cm}$. 
encontravam envoltos por tecido conjuntivo frouxo ou intertubular, semelhante ao descrito por Banks (1992), George \& Castro (1998), Gartner (1999), Kerr (2000) e Junqueira \& Carneiro (2004). Nos túbulos seminíferos encontram-se células da linhagem germinativa desde o estágio de espermatogônia até a espermátide, muito semelhante ao espermatozóide, assim como descrito por O’Donnel et al. (2001) (Fig.3).

0 epidídimo encontrou-se como um tubo enovelado, dividido em cabeça, corpo e cauda, cuja cauda se continuava como ducto deferente. 0 epitélio dos tubos epididimários apresentava-se pseudoestratificado prismático possuindo cílios do tipo estereocílios, e a camada de revestimento era formada por lâmina própria (tecido conjuntivo frouxo) altamente vascularizado semelhante ao descrito por Banks (1992), George \& Castro (1998), Gartner (1999), Kerr (2000) e Junqueira \& Carneiro (2004) (Fig.3).

0 ducto deferente apresentava uma luz formada por uma mucosa, circundada por duas camadas musculares longitudinais, ao redor da luz e circular, na periferia do ducto. A mucosa emboçava um epitélio pseudoestratificado ciliado ao microscópio óptico, semelhante ao visto no epidídimo (Fig.3).

O pênis de Procyon cancrivorus era formado pelo osso peniano, também chamado de báculo, pela uretra peniana,

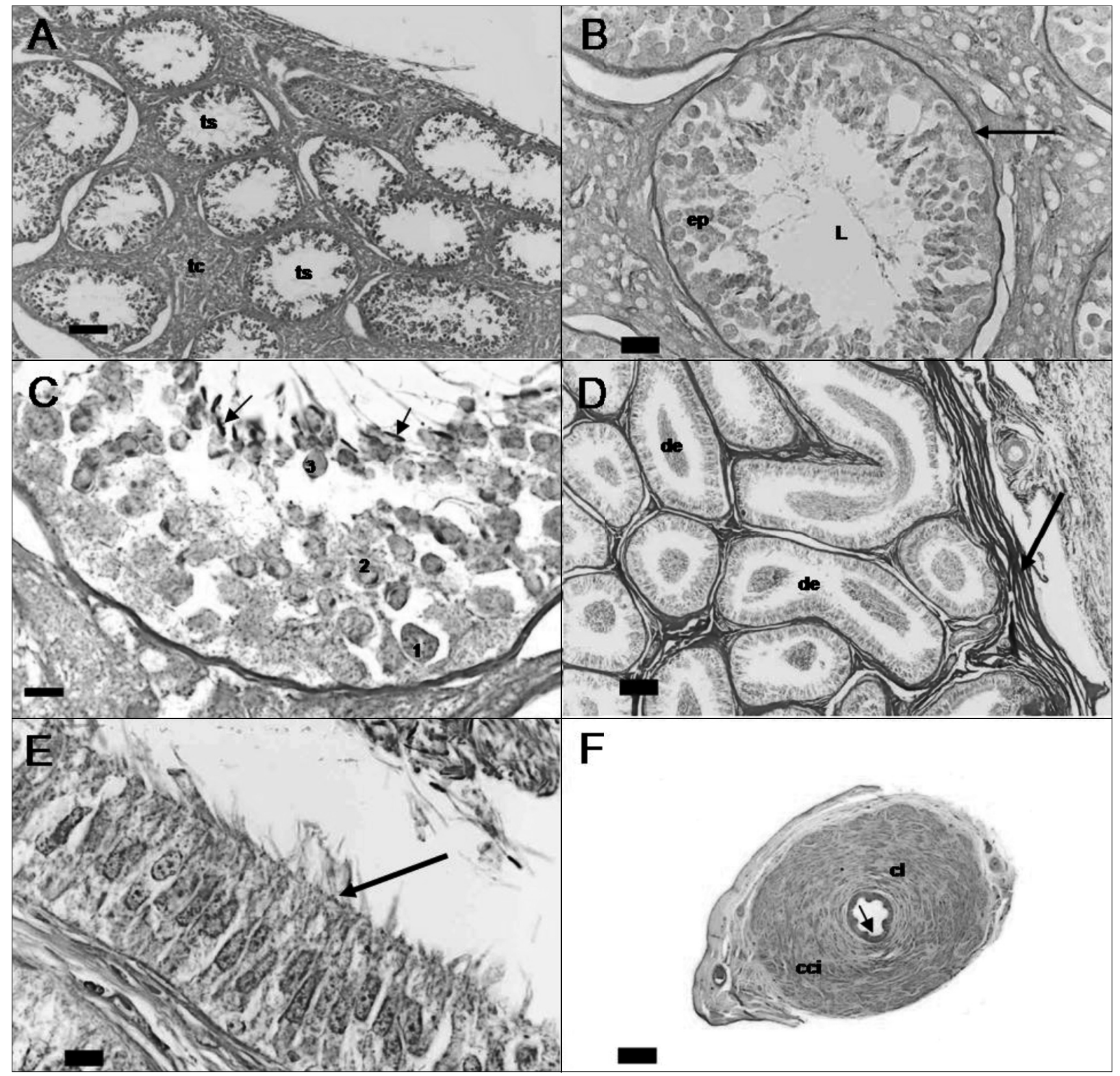

Fig.3. Histologia dos órgãos genitais masculinos do Procyon cancrivorus. (A) Túbulos seminíferos (ts) e ao seu redor tecido conjuntivo intertubular (tc). HE, $90 \mu \mathrm{m}$. (B) Detalhe do túbulo seminífero e epitélio germinativo (ep) suportado por uma membrana basal marcada pela reação de PAS (seta) e a luz do túbulo (L). PAS, $20 \mu \mathrm{m}$. (C) Maior aumento das célu-

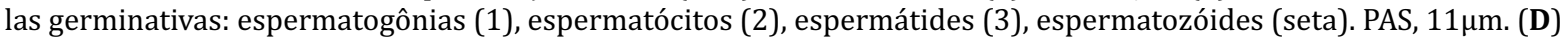
Ductos epididimários (de) e camada de revestimento fibromuscular (seta). Picrosirius, $90 \mu \mathrm{m}$. (E) Epitélio pseudiestratificado estereociliado do ducto epididimário (seta). HE, $11 \mu \mathrm{m}$. (F) Epitélio do ducto deferente (seta), circundado por uma camada longitudinal (cl) e circular (cci) de músculo liso. HE, $220 \mu \mathrm{m}$. 
que passa dorsalmente a ele, pelos corpos cavernoso e esponjoso e pelo tecido erétil. Externamente o pênis era envolvido por um epitélio de revestimento da epiderme (Fig.4).

A próstata era formada por glândulas exócrinas túbulo-alveolares, cuja porção secretora exibia um epitélio simples colunar e a camada de revestimento era do tipo fibroelástica, contendo grande quantidade de músculo liso, de acordo com Cardoso et al. (1985), Banks (1992), George \& Castro (1998), Gartner (1999), Kerr (2000) e Junqueira \& Carneiro (2004) (Fig.4).
A ampola do ducto deferente era uma dilatação formada no ducto deferente antes deste adentrar na próstata. Seu epitélio era pregueado e espesso e as vesículas seminais desembocavam na sua porção final, indo de encontro ao descrito por Banks (1992), George \& Castro (1998), Gartner (1999), Kerr (2000) e Junqueira \& Carneiro (2004) (Fig.4).

\section{CONCLUSÕES}

Após estes estudos iniciais em Procyon cancrivorus, julgamos concluir que macro e microscopicamente o sistema

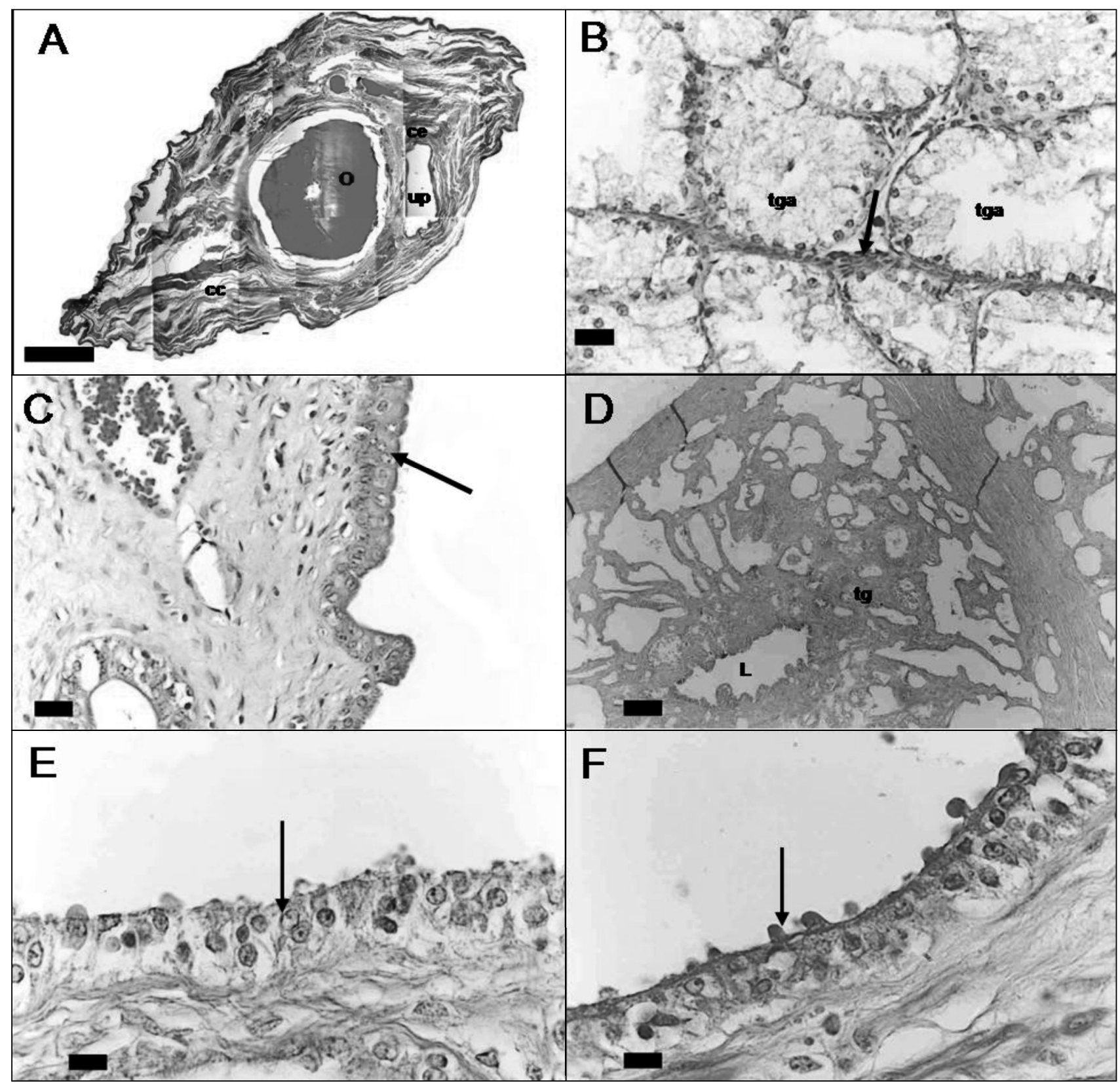

Fig.4. Histologia dos órgãos genitais masculinos do Procyon cancrivorus. (A) Região do osso peniano constituída por: osso do báculo (0), uretra peniana (up), corpo esponjoso (ce) e corpo cavernoso (cc). Tricromo de Masson, $220 \mu \mathrm{m}$. (B) Porção glandular da próstata, constituída por glândulas túbulo-alveolares (gta) circundadas por tecido conjuntivo e músculo liso (seta). HE, $20 \mu \mathrm{m}$. (C) Detalhe do epitélio de transição da uretra prostática (seta). HE, $20 \mu \mathrm{m}$. (D) Luz do ducto da ampola do ducto deferente (L) e tecido glandular (tg). PAS, $220 \mu \mathrm{m}$. (E) Porção secretora da ampola do ducto deferente, formada por epitélio prismático (seta). PAS, $11 \mu \mathrm{m}$. (F) Porção secretora da ampola do ducto deferente, cujas células estão realizando exocitose, secreção apócrina (seta). HE, $220 \mu \mathrm{m}$. 
reprodutor masculino de Procyon cancrivorus assemelha-se com o do cão e gato doméstico, já que possui o osso peniano ou báculo e não possui o par de glândulas bulbouretrais.

Outro ponto a ser esclarecido refere-se à glande possuir formato de altere, sendo a única estrutura anatômica diferente dos carnívoros domésticos e microscopicamente, as estruturas analisadas pela histologia convencional assemelham-se as descritas para os mamíferos domésticos.

Agradecimentos.- À Fundação de Amparo à Pesquisa do Estado de São Paulo (FAPESP) que nos permitiu o desenvolvimento deste trabalho através de projeto de Auxílio Pesquisa.

\section{REFERÊNCIAS}

Banks W.J. 1992. Histologia Veterinária Aplicada. 2ª̣ ed. Manole, São Paulo. 629 p.

Bellatine T., Mançanares C.A.F., Franciolli A.L.R., Ambrósio C.E., Martins D.S., Miglino M.A. \& Carvalho A.F. 2010. Estudo morfofuncional das glândulas mamárias de mão-pelada, Procyon cancrivorus. Pesq. Vet. Bras. 30 (8):689-695.

Cardoso F.M., Figueiredo E., Godinho H. \& Coser A.M. 1985. Variação sazonal da atividade secretória das glândulas genitais acessórias masculinas de tatus (Dasypus novemcinctus Linnaeus, 1758). Revta Bras. Biol. 45(4):507-514.

Dyce K.M., Sack W.O. \& Wesing C.J.G. 1997. Tratado de Anatomia Veterinária. $2^{\mathrm{a}}$ ed. Guanabara Koogan, Rio de Janeiro, p.147-155.

Ejercito C.L., Cai L., Htwe K.K., Taki M., Inoshima Y., Kondo T., Kano C., Abe S., Shirota K., Sugimoto T., Yamaguchi T., Fukushi H., Minamoto N., Kinjo T., Isogai E. \& Hirai K. 1993. Serological evidence of Coxiella burnetii infection in wild animals in Japan. J. Wildl. Dis. 29(3):481-484.

Ellenport C.R. 1986. Aparelho urogenital, p.138-139. In: Getty R. (Ed.), Sisson e Grossman's Anatomia dos Animais Doméstcos. Vol.1.5a ed. Guanabara Koogan, Rio de Janeiro,.

Franciolli A.L.R., Costa G.M., Mançanares C.A.F., Martins D.S., Ambrósio C.E., Miglino M.A. \& Carvalho A.F. 2007. Morfologia dos órgãos genitais masculinos de quati (Nasua nasua Linnaeus, 1766). Biotemas 20(1):27-36.
Gartner L.P. \& Hiatt J.L. 1999. Tratado de Histologia. Guanabara Koogan, Rio de Janeiro, p.377-394.

George L.L. \& Castro R.R.L. 1998. Histologia Comparada. $2^{\underline{a}}$ ed. Roca, São Paulo, p.227-236.

Hafez E.S.E. \& Hafez B. 2004. Reprodução Animal. 7a ed. Manole, São Paulo, p.3, 7 e $97-98$.

Junqueira L.C.V., Bignonas G. \& Bretan R.P. 1979. Picrosirius staining plus polarization microscopy: A specific method for collagen detection in the tissue sections. Histochem. J. 11:447-255.

Junqueira L.C. \& Carneiro J. 2004. Histologia Básica.10a ed. Guanabara Koogan, Rio de Janeiro, p.415-431.

Kerr J.B. 2000. Atlas de Anatomia Funcional. Artes Médicas, São Paulo, p.339-358.

Labate A.S., Nunes A.L.V. \& Gomes M.S. 2001. Order Carnívora, family Procionidae (raccoons, kinkajus), p.317-322. In: Fowler M.E. \& Cubas Z.S. (Eds), Biology, Medicine and Surgery of South American Wild Animals. Iowa State University Press, Ames. 536p.

Lillie R.D. \& Fulmer H.M. 1976. Histopathologic Technic and Practical Histochemistry. $4^{\text {th }}$ ed. McGraw Hill, New York. 942p.

Machida N., Kiryu K., Oh-ishi K., Kanda E., Izumisawa N. \& Nakamura T. 1993. Pathology and epidemiology of canine distemper in raccoon dogs (Nyctereutes procyonoides). J. Comp. Pathol. 108(4):383-392.

Menezes D.J.A., Assis Neto A.C., Oliveira M.F., Farias E.C., Miglino M.A., Pereira G.R., Ambrósio C.E., Ferraz M.S. \& Carvalho M.A.M. 2010. Morfologia das glândulas genitais acessórias em cutias (Dasyprocta prymnolopha Wagler, 1831). Pesq. Vet. Bras. 30(9):793-797.

O’Donnel L., Robertson K.M., Jones M.E. \& Simpson E.R. 2001. Estrogen and spermatogenesis. Endocrine Rev. 22(3):289-318.

Rodrigues A.F.S.F., Daemon E. \& Massard C.L. 2007. Morphological and morphometrical characterization of gametocytes of Hepatozoon procyonis Richards, 1961 (Protista, Apicomplexa) from a Brazilian wild procionid Nasua nasua and Procyon cancrivorus (Carnivora, Procyonidae). Parasitol. Res. 100:347-350.

Tolosa E.M.C., Rodrigues C.J., Behmer O.A. \& Freitas-Neto A.G. 2003. Manual de Técnicas para Histologia Normal e Patológica. $2^{\text {a }}$ ed. Manole, São Paulo. 331p.

Zeller U. 1999. Mammalian reproduction: origin and evolutionary transformations. Zoologischer Anzeiger 238(1/2):117-130. 